\title{
ADSA Foundation Scholar Award: Influencing hepatic metabolism: Can nutrient partitioning be modulated to optimize metabolic health in the transition dairy cow?
}

H. M. White*

Department of Dairy Science, University of Wisconsin, Madison 53706

\begin{abstract}
Hepatic de novo production of glucose and oxidation of fatty acids are critical in supporting milk production during the transition to lactation period. During this period of metabolic challenge, there is an increase in fatty acids taken up by the liver. Although the primary fate for these fatty acids is complete oxidation, alternative fates include incomplete oxidation via ketogenesis, storage within the liver as triglycerides (TG), and secretion of TG within very low density lipoproteins. Influencing the relative capacity of these pathways, and thus shifting nutrient partitioning, may allow for improved hepatic efficiency and metabolic health. Hepatic nutrient partitioning reflects complex regulation of key metabolic pathways by factors such as fatty acids and other substrates. Relative flux of fatty acid through oxidation or re-esterification to TG leads to the onset of metabolic disorders that are associated with negative production outcomes, such as hyperketonemia and fatty liver. Although recent work has focused on understanding how stored TG are lipolyzed for subsequent oxidation, the mechanism and regulation of this remains unclear. The source of mobilized fatty acids is similarly important, both in terms of amount and profile of fatty acids mobilized. There is likely a complex, coordinated whole-body response, given that fatty acids mobilized from adipose tissue affect hepatic regulation. Fatty acids mobilized from adipose tissue have regulatory effects on genes such as pyruvate carboxylase; however, in vivo work suggests there may also be other influences resulting in differential regulation between cows that subsequently develop sub-clinical ketosis and those that do not. Optimizing nutrient partitioning between critical metabolic pathways may allow for nutritional opportunities to reduce incidence of metabolic challenges and improve feed efficiency. Although further research is needed to continue refining our understanding of the
\end{abstract}

Received December 23, 2019.

Accepted March 26, 2020.

*Corresponding author: heather.white@wisc.edu intricate balance regulating hepatic metabolism, shifting nutrient partitioning may be key in supporting both efficiency and metabolic health.

Key words: gluconeogenesis, oxidation, fatty acids, negative energy balance

\section{INTRODUCTION}

The transition to lactation period has been widely recognized as the most challenging period in a dairy cow's lactational cycle (Grummer, 1993; Goff and Horst, 1997; Drackley, 1999); however, it also holds great opportunity for improvements in animal efficiency and health. As predicted by Drackley (1999), "improved understanding of this frontier of the biology, nutrition, and management of cows during the transition period will provide the largest gains in productivity and profitability during the next decade," which has undoubtedly been the case. Yet, the answers bring additional questions, and as knowledge and methodology advance, our ability to dig deeper improves. Despite the research focused on the transition period over the last 2 decades, a great deal remains to be elucidated about the intricate balance of nutrient partitioning and utilization during this period.

The basis for many of the challenges associated with the transition to lactation period are rooted within energy balance. Voluntary feed intake reduction around the time of calving, coupled with increased energy requirements to meet the needs of lactation, result in cows entering a state of negative energy balance (NEB) during the peripartum period. During periods of NEB, triglycerides (TG) are mobilized from adipose stores and are transported to the liver as nonesterified fatty acids (NEFA) and glycerol, providing an energetic and gluconeogenic precursor (Dole, 1956; Gordon and Cherkes, 1956). The onset of NEB also creates a deficiency in glucose and amino acids, as decreased DMI also limits gluconeogenic precursors and amino acids available to the liver for metabolism. Likewise, these limitations result in shifts in predominant precursors and nutrient partitioning. Although not all cows lose BCS across the 
transition to lactation period, those that do lose BCS are more likely to have negative effects on metabolic health and fertility (Barletta et al., 2017; Rathbun et al., 2017). In this light, it stands to reason that the shifts in nutrient partitioning and utilization during the peripartum period are likely critical in determining potential success, production, and efficiency during both the transition to lactation period, as well as the entire lactation period.

This review will highlight the recent findings and some of the remaining gaps in understanding nutrient partitioning, efficiency, and metabolic health during the transition to the lactation period. Novel insights into the complex regulation of whole-body nutrient partitioning and utilization, and connections between biological findings and applied nutrition and management tools will also be presented.

\section{HEPATIC NUTRIENT PARTITIONING DURING THE PERIPARTUM PERIOD}

At the onset of NEB, TG are mobilized from the adipose tissue and transported through the blood as NEFA and glycerol to provide precursors for energy or TG synthesis in other tissues. Within the liver, fatty acids are $\beta$-oxidized to acetyl-CoA units with 4 possible fates (Figure 1): complete oxidation through the tricarboxylic acid (TCA) cycle, incomplete oxidation through ketogenesis, TG synthesis and packaging as very-low density lipoprotein for export from the liver, or TG synthesis for storage as liver lipids (reviewed by Grummer, 1993). Fatty acids are proportionally taken up by the liver relative to concentration and blood flow (Emery et al., 1992; Reynolds et al., 2003) and can exceed TCA-cycle capacity during peak adipose tissue mobilization, leading to increased production of ketone bodies and deposition of TG (White, 2015). If flux of NEFA carbon through these alternative fates is excessive, cows may experience metabolic disorders such as hyperketonemia (HYK) or hepatic lipidosis (White, 2015), which contribute greatly to the cost of dairy production through treatment cost, lost milk, reduced reproductive efficiency, and involuntary culling (Bobe et al., 2004; McArt et al., 2014).

Despite the potential negative outcomes of metabolic disorders, mobilization of TG from adipose tissue serves a critical function during the transition to lactation period. Mobilized TG from adipose tissue provides valuable milk fat precursors for mammary gland utilization (Palmquist, 2006). Hepatic uptake of glycerol can provide a gluconeogenic precursor during feed restriction or NEB (Huntington, 1990). Furthermore, oxidative phosphorylation of energy equivalents generated during TCA cycle oxidation of NEFA is essential to fuel hepatic gluconeogenesis, ammonia detoxification via the urea cycle, and other hepatic functions (Adewuyi et al., 2005), although these pathways may be hindered by accumulation of lipids within hepatocytes (Grummer, 1993; Strang et al., 1998; Drackley, 1999; Zhu et al., 2000; Bobe et al., 2004). The complete oxidation of fatty acids and other oxidative substrates (e.g., lactate, propionate) may generate more energy than what is needed within the hepatocyte, resulting in negative feedback on the TCA cycle, based on ATP and NADH concentrations (Berg et al., 2002). Ketone bodies produced by ketogenesis can be used as an energy source by other tissues, including the mammary gland, central nervous system, heart, and muscle, allowing for export of energy from the liver (Berg et al., 2002). It is only when the production rate of ketone bodies exceeds peripheral tissue uptake that HYK occurs (Adewuyi et al., 2005). The many uses and fates of mobilized fatty acids highlights the intricate balance of nutrient partitioning during the transition period.

Although liver lipid content increases peripartum in dairy cows, it decreases as lactation progresses (Rukkwamsuk et al., 1999, 2000; Greenfield et al., 2000). Although it is assumed that both re-esterification and subsequent lipolysis occur in the liver (Drackley, 1999), the regulation of stored lipid "remobilization" within hepatocytes has not been fully elucidated and raises questions regarding the role of hepatic fatty acid storage for subsequent use. It is clear that mobilized NEFA available for hepatic uptake may not merely serve as inert energy precursors, but also as regulators of hepatic enzymes involved in gluconeogenesis and fatty acid transport (Bionaz et al., 2008; White et al., 2011a,b, 2012; Chandler and White, 2019). Additionally, there may be preferential utilization or storage of some fatty acids (Thompson et al., 1975; Chen and Cunnane, 1992; Rukkwamsuk et al., 2000; Weld et al., 2019b). The potential uniting factors between these 2 aspects is there may be fatty acid regulation of the pyruvate carboxylase gene $(\boldsymbol{P C})$, which potentially increases complete oxidative capacity (White et al., 2011a,b; 2012; White, 2015), and hepatic lipid-associated proteins, which control storage or remobilization of stored fatty acids (Holdorf et al., 2017; Erb and White, 2019a,c,d). A lipid-associated protein of specific interest has been patatin-like phospholipase domain-containing protein 3 (PNPLA3). Studies in human hepatocytes focused on understanding nonalcoholic liver disease have demonstrated an inactivated isoform of PNPLA3 present in the cells cause a significant increase in TG accumulation (Huang et al., 2010). In dairy cows, it has been shown that PNPLA3 mRNA is decreased during feed restriction and at calving (McCann et al., 2014). Protein abundance is inversely related to hepatic lipid 
accumulation across the transition to lactation period (Pralle et al., 2015; Pralle et al., 2019). Protein abundance of PNPLA3 was knocked down within primary bovine hepatocytes using small interfering RNA to examine the direct effect of PNPLA3 on lipid accumulation, and a significant increase in cellular lipids was observed with small interfering RNA knockdown (Erb and White, 2019b). Considered together, the lipolytic function of PNPLA3, the potential role of PNPLA3 in nonalcoholic fatty liver disease onset in other species (Huang et al., 2010; Rotman et al., 2010; Speliotes et al., 2010; Corbin et al., 2013), along with the patterns of PNPLA3 protein abundance in transition dairy cows, suggest that PNPLA3 may play a role in remobilization of stored lipids (Figure 2). Our understanding of hepatic regulation of fatty acid re-esterification, storage, and remobilization is not yet complete; however, the excit- ing findings to date suggest an intricate regulation of hepatic oxidation, storage, and mobilization pathways.

Dogmatically, both HYK and hepatic lipidosis have been considered in a negative light. Although there are negative outcomes associated with each metabolic state, most thoroughly examined by McArt and colleagues (McArt et al., 2014), the thresholds used to diagnose metabolic disorders are points at which negative outcomes are statistically more likely to occur. Unfortunately, this does not capture animal-to-animal variation in response to metabolic challenge, which will be discussed more in a later section. It is important to remember these alternative pathways have important roles within homeostasis and homeorhesis and likely represent alternative nutrient partitioning or utilization that is essential when primary fuel sources are limited. Viewing HYK as an indicator of metabolic imbalance,

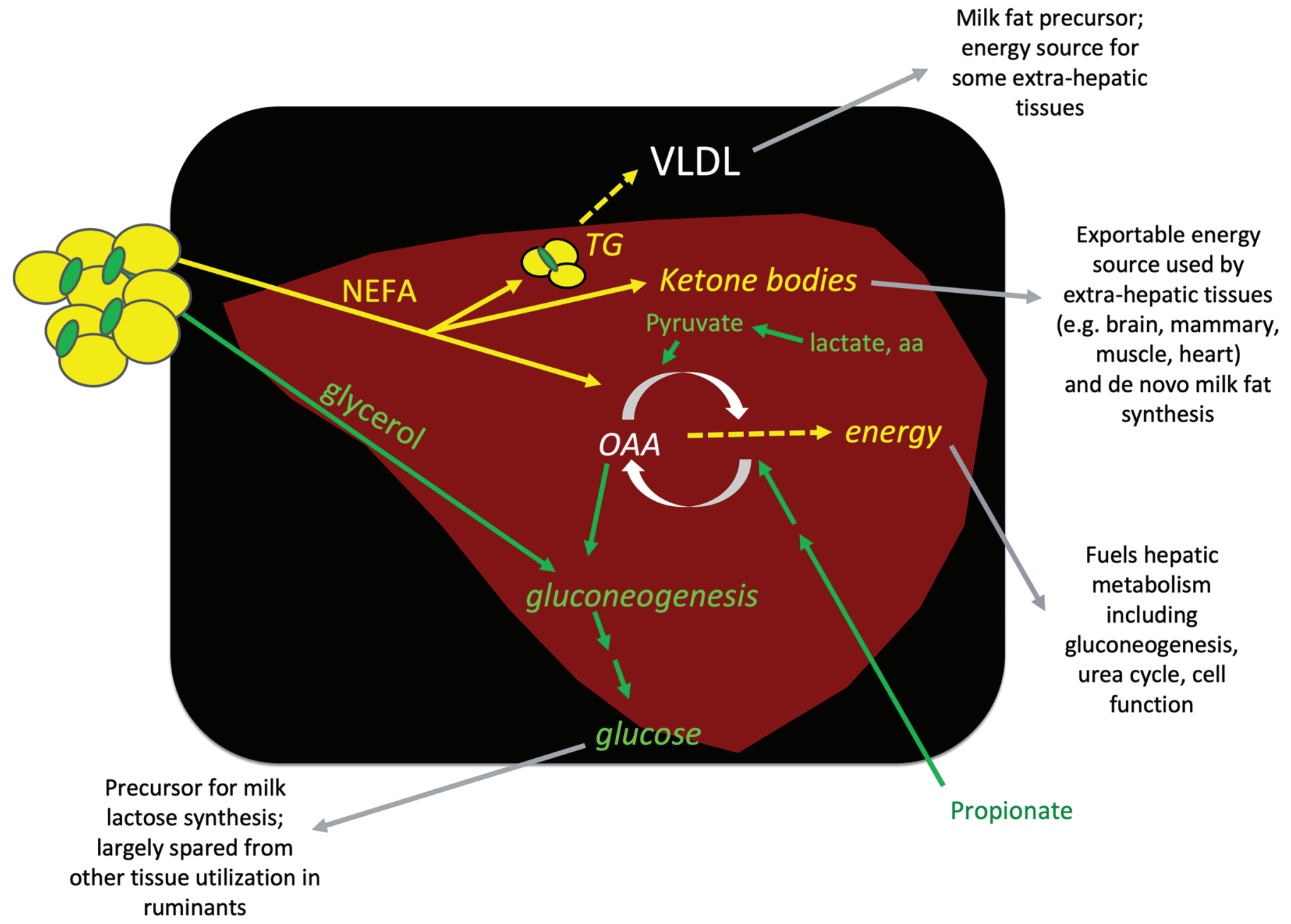

Figure 1. Hepatic nutrient partitioning of key energy and glucose precursors across primary metabolic pathways and extra-hepatic fates for pathway products. NEFA $=$ nonesterified fatty acids, OAA $=$ oxaloacetate, $\mathrm{TG}=$ triglycerides, $\mathrm{VLDL}=$ very low density lipoproteins, aa $=$ amino acids. 
Hepatic uptake of FA increases during NEB

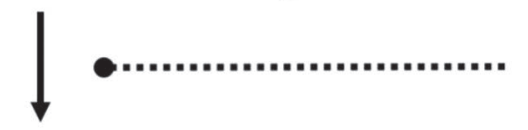

FA likely contribute to hepatic PNPLA3 regulation

Concurrent decreased PNPLA3 abundance

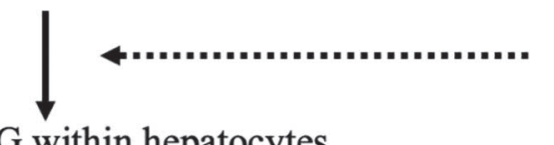

\author{
Knockdown of PNPLA3 in hepatocytes further \\ increases cellular TG accumulation
}

FA stored as TG within hepatocytes

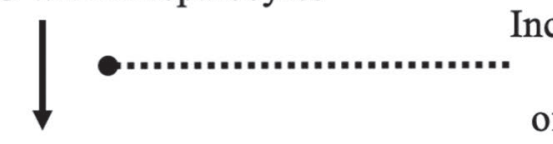

Increased lipolytic action of PNPLA3, interacting with other lipolytic proteins, may allow for "remobilization" of stored TG, regulatory stimulus not yet fully understood

Abundance of PNPLA3 increases postpartum; Hepatic TG decreases

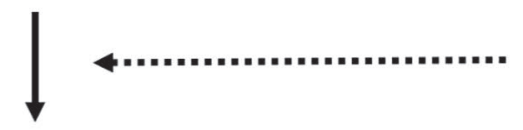

PNPLA3 and hepatic TG are correlated over time

\title{
Hepatic TG content returns to original state
}

Figure 2. Proposed mechanism for role of hepatic patatin-like phospholipase domain-containing protein 3 (PNPLA3) on hepatic triglyceride (TG). Potential influencers $(\bullet . .$.$) and known relationships (-\cdots)$ are noted. FA $=$ fatty acid, NEB $=$ negative energy balance.

rather than a "disease," may guide us to identify key factors that lead to metabolic dysfunction. Knowing these key factors will further favor precision animal nutrition and animal health. Further examination of other contributing factors such as cow comfort, inflammation, or management should continue, as they ultimately interact to improve animal health and production.

\section{POTENTIAL IMPROVEMENTS IN FEED EFFICIENCY THROUGH ALTERING NUTRIENT PARTITIONING}

Understanding the mechanism of hepatic nutrient partitioning provides potential opportunities to improve feed efficiency by shifting nutrient flux or utilization. These routes of improvement could be through decreased hepatic lipid accumulation or inflammatory stress to permit efficient hepatic function, direct influence on complete oxidative or gluconeogenic capacity through regulation or provision of optimal precursors, or improved mammary utilization of energetic precursors. Nutritional and managerial interventions to mitigate hepatic lipidosis, and their potential impact on hepatic function, have been reviewed previously (Grummer, 1993; Bobe et al., 2004). Methyl-donors such as choline and methionine have been examined with increasing interest as our understanding of hepatic inflammation, oxidative stress, and lipid trafficking improves. While choline is traditionally known for decreasing liver lipid accumulation during the transition to lactation period, involvement in methyl-carbon metabolism and nutri- ent partitioning is now being explored and may explain increases in milk production observed in vivo (Janovick Guretzky et al., 2006; Elek et al., 2008; Zom et al., 2011; Lima et al., 2012; Zenobi et al., 2018). A current comprehensive review of the influence of methyl-donors on hepatic function highlights the roles of betaine, choline, folate, and methionine on liver function (McFadden et al., 2020) and will not be covered further here.

Progress has been made in more precisely formulating rations to better match absorbed nutrients with tissue nutrient requirements as well. Increased propionate production in the rumen, whether through optimizing starch feeding or use of ionophores, is well-established in providing a valuable gluconeogenic precursor to the liver that leads to an increase in milk production (McGuffey et al., 2001; Aschenbach et al., 2010; Hall and Mertens, 2017; Schären et al., 2018). Better matching precursors to metabolic pathways may also improve feed efficiency while improving metabolic health, through influencing nutrient partitioning. Postpartum supplementation of ammoniated condensed whey reduced BHB and NEFA, and increased glucose concentrations in the immediate postpartum period and tended to reduce incidence of HYK (Caputo Oliveira et al., 2019). These improvements in metabolic health coincided with maintained milk production and improved feed efficiency, which may have reflected increased propionate from ruminal lactate fermentation for hepatic gluconeogenesis. Additionally, the increased ratio of $P C$ to cytosolic phosphoenolpyruvate carboxykinase gene expression, 
together with decreased plasma BHB and the tendency for lower hepatic TG, suggests potential for increased complete oxidation and a shift in nutrient partitioning (Caputo Oliveira et al., 2019). The observed improvement in feed efficiency was in terms of both energy and nitrogen efficiency and should be further examined in future research.

Nutrient partitioning may influence feed efficiency even when dietary interventions are not involved. With the concerted effort of the dairy industry to focus on improvements in feed efficiency, there have been increased efforts to understand the source of individual cow variation in feed efficiency (Herd and Arthur, 2009; Potts et al., 2015; VandeHaar et al., 2016). The majority of this research is being done during mid-lactation when animals are not in NEB; however, there is undoubtedly an effect of the initial postpartum period on the lactation as a whole. Considering mobilized TG from body stores provide an energy source, it is important to note that residual feed intake (RFI) calculations include body weight change, whereas this potential contribution is ignored in more gross scale indicators of feed efficiency. In theory, if an animal is more feed efficient because of reliance on stored body reserves, even in mid-lactation, that animal may also be predisposed to metabolic challenges during subsequent peripartum periods. This was examined previously (Rathbun et al., 2017) and no effect of a previous lactation's RFI on future lactation HYK status was noted. The question that remains is how metabolic or infectious health incidences during the peripartum period influence feed efficiency during a specific lactation. Although data are often available for lactational health events before research experiments, diagnostic protocols for management practices are routinely and justifiably less rigorous than research diagnostic protocols. The result of this is that records of health incidences do not provide true negative cases as it is impossible to know if negative cases were merely undetected positive cases (Pralle and White, 2020). Thus, intentional research is required to answer these questions. Dependent on the answer, which may be different based on the health incidence, this will either put further emphasis on preventing health disruptions or provide insight to influence management decisions on cows that have known risk or propensity for certain health outcomes. Aside from influences of health incidences, nutrient partitioning may represent a portion of the individual cow difference in RFI. When all external variables are consistent (e.g., weather, housing, management), disparity between more and less efficient cows may be partially explained by differences in post-absorptive nutrient utilization. Early investigations comparing mammary uptake of energy equivalents (NEFA, BHB, TG, glucose) between high- and low-efficient cows suggest that when all other factors are considered, mammary uptake of more efficient cows may sequester a greater percentage of circulating energy metabolites (Martin et al., 2019) and justifies continued investigations.

\section{ADIPOSE TISSUE MOBILIZATION AND DOWNSTREAM REGULATION BY FATTY ACIDS}

During NEB associated with the transition period or during feed restriction, TG from adipose tissue will be mobilized, releasing NEFA and glycerol into circulation. What remains unclear is the mechanism of adipose tissue lipolysis in ruminants. Traditionally, activation of hormone-sensitive lipase by protein kinase A was thought to be the primary control point for lipolysis (Koltes and Spurlock, 2011). Advances in understanding the regulation of adipose lipolysis from rodent models have shed light on the role of perilipin (PLIN), abhydrolase domain containing protein 5 (ABHD5), and adipose triglyceride lipase (ATGL) in coordinated lipolysis and metabolic disorders (Granneman et al., 2007, 2009; Greenberg et al., 2011). Although phosphorylated PLIN is increased after calving, abundance of ATGL, the rate-limiting lipase in other species, is notably consistent in abundance in dairy cows during the time of adipose mobilization (Koltes and Spurlock, 2011; Erb et al., 2017). It has been suggested that ABHD5 is an activator of ATGL (Sanders et al., 2015) and interacts with PLIN, and potentially other lipases, on the lipid droplet (Lass et al., 2006; Ghosh et al., 2008; Akiyama et al., 2008). Given this disconnect, continued work is necessary to identify the rate-limiting enzyme or activation step of adipose tissue lipolysis.

Despite the potential gaps in understanding of mechanism or regulation of lipolysis, our understanding of the metabolism and regulatory effect of mobilized NEFA continues to increase. In ruminants, primary adipose tissue fatty acids are C16:0, C18:0, and C18:1 (Rukkwamsuk et al., 2000; Sato and Inoue, 2006; Meier et al., 2013), which are thus expected to be increased in plasma postpartum, as cows mobilize fatty acids from adipose tissue. Although the majority of in vivo research on adipose tissue focuses on subcutaneous depots due to accessibility, we cannot ignore other adipose depots and must acknowledge that the regulation and metabolic activity of these visceral depots may be different (Ji et al., 2014). The fatty acid composition across depots varies with C18:0 contributing relatively less than C16:0 and C18:1 in subcutaneous adipose depots, but relatively more in visceral adipose depots (Sato and Inoue, 2006; Meier et al., 2013). Given that TG are also mobilized from these visceral adipose depots during the peripartum period (Schäfers et al., 2018), further 
work is needed to understand their contribution to the circulating fatty acid pool, especially considering the proximity to the liver. Given that some fatty acids have known effect on regulation of hepatic gene expression (White et al., 2011a; Bionaz et al., 2012; White et al., 2012), preferential mobilization of fatty acid, or other means of altering plasma NEFA profile, may allow for differential regulation of genes. Additionally, profile of NEFA could influence the fate of certain fatty acids (i.e., oxidation to energy vs. storage) after hepatic uptake. For example, appearance of specific fatty acids in plasma and subsequent storage of TG within the liver is expected, with the exception of stearic acid (C18:0), which does not appear to accumulate within stored liver TG to a similar extent as other fatty acids (Rukkwamsuk et al., 2000; Weld et al., 2019a). This has also been demonstrated in sheep, hamsters, and rats (Wang and Koo, 1993; Thompson et al., 1975), which suggests that preferential oxidation or utilization of some fatty acids may occur. If this is the case, influencing circulating NEFA profile, either through diet or physiology, could influence downstream hepatic metabolism via regulatory effects or leverage preferential fates.

Once mobilized, fatty acids can have bioactive and regulatory roles across tissues including the liver (discussed above) and mammary gland (Bernard et al., 2008; Mach et al., 2011; Ibeagha-Awemu et al., 2016) which appear to be fatty acid specific; however, fatty acids can also influence insulin sensitivity (Pires et al., 2007; Mathews et al., 2016; Weber et al., 2016; McFadden and Rico, 2019). Although insulin resistance was previously generalized to over-conditioned cows, it may be related to activity of specific fatty acids as it is to BCS or BCS loss. Interestingly, even when prepartum BCS ( $\leq 3.0$ vs. $\geq 4.0)$ had minimal effects on insulin tolerance, high prepartum BCS had a negative effect on the ability of the cow to recover blood glucose concentrations following an insulin challenge (Samii et al., 2019). Given that patterns of insulin resistance have been noted across cows of varying BCS (Weber et al., 2016; Samii et al., 2019), the role of fatty acids in whole-body regulation should continue to be explored.

Within the context of this review, the regulation of downstream pathways by circulating fatty acids during periods of TG mobilization from adipose tissue may be further confounded by the fact that induction of postpartum fatty liver (Rukkwamsuk et al., 2000) or occurrence of HYK (Weld et al., 2019b) result in differences in the postpartum circulating fatty acid profile. Hepatic genes have been previously demonstrated to be responsive to increasing concentration and changes in fatty acid composition (White et al., 2012), yet the subtle differences in the circulating fatty acid profile in cows with or without HYK do not appear to account for the differential response of hepatic $P C$ in vivo (Weld et al., 2019a) or in vitro (Weld et al., 2019b). It is important to note that this example is centered on a small subset of hepatic genes related to gluconeogenesis and TCA cycle oxidation, and little is known about the downstream effect of these differences on other pathways or across tissues. Further research is needed to fully elucidate the role of fatty acids in hepatic gene regulation, systemic insulin sensitivity, and nutrient partitioning.

\section{OPPORTUNITIES FOR FUTURE RESEARCH}

Countless advances in understanding the transition to lactation period, nutrient partitioning, and tissuelevel regulation of metabolism have been made over the last 2 decades; however, the unanswered questions and remaining opportunities are still numerous. Improving cow health, welfare, longevity, and feed efficiency continue to be key focuses, because they will continue to be critical determinants of farm and environmental sustainability and profitability, as well as drivers of consumer perception.

Although many aspects of nutrient partitioning were covered within this review, there are just as many interrelated areas that have not been included. Cursory reviews of complex topics such as heat stress (Baumgard and Rhoads, 2013), inflammation (Sordillo et al., 2009; Sordillo, 2016; Bradford and Swartz, 2019) and fetal programming (González-Recio et al., 2012; Opsomer et al., 2017; Van Eetvelde and Opsomer, 2017) would serve an injustice, as complete recent reviews are available. Not only are these topics complex in their own right, but future progress will undoubtedly be made by understanding the interactions of these challenges and the ones discussed herein, both during the transition to lactation period and throughout lactation.

Within the scope of this review, many knowledge gaps remain. Three pivot points related to nutrient partitioning warrant continued focus (Figure 3). Understanding the regulation of lipolysis, preferential storage (in adipose or liver) or oxidation, as well as the regulatory effect of specific fatty acids may provide insights into how strategically increasing or decreasing specific fatty acids could provide benefit. Downstream of hepatic fatty acid uptake, the potential to increase TCA cycle capacity, and whether that is beneficial at the cellular, tissue, and whole-body level, is of great interest. The long-standing assumption that re-esterification of fatty acids to TG for storage or export and the opposing subsequent lipolysis of these stored TG for $\beta$-oxidation and subsequent TCA cycle oxidation lacks resolution of understanding. Are there steps or pivotal points in this process that are committal and 


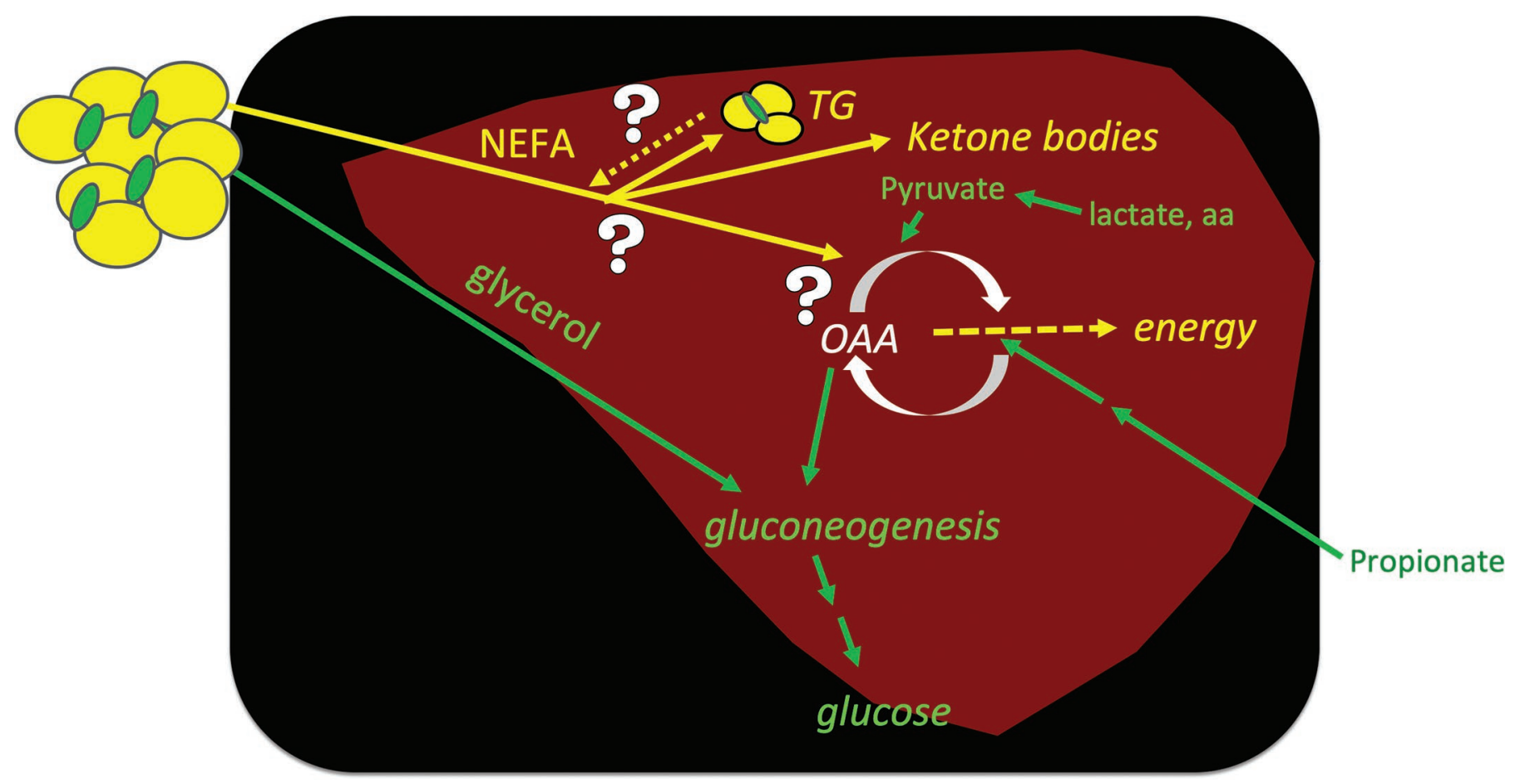

Figure 3. Hepatic nutrient partitioning across primary metabolic pathways with key remaining questions highlighted. Counterclockwise from top left to bottom right: (1) What is the mechanism and regulation of lipolysis of stored triglycerides (TG) in the liver? (2) Is there preferential storage or oxidation of fatty acids and can strategically influencing fatty acid profile have an effect on hepatic nutrient partitioning? (3) Is there potential to increase TCA cycle capacity and would an increase be beneficial at the cellular, tissue, and whole-body level? NEFA = nonesterified fatty acids, OAA $=$ oxaloacetate, $\mathrm{TCA}$ cycle $=$ tricarboxylic acid cycle, $\mathrm{TG}=$ triglycerides, aa $=$ amino acids.

non-reversible? What are the key limiting enzymes, and can we influence net flux of fatty acids and acetyl-CoA building blocks by regulating these pathways? Adding clarity to differences in hepatic or whole-body regulation that precede metabolic challenges (e.g., HYK) will be critical in decreasing risk for these imbalances and improving health during the transition to lactation period. Finally, unexplained individual animal variation in cow success during the transition to lactation period or differences in feed efficiency, should be viewed as an opportunity to gain insight into nutrient partitioning and utilization, rather than an outlier to be ignored.

\section{ACKNOWLEDGMENTS}

The author extends gratitude to colleagues and collaborators, the countless undergraduate and graduate students, and farm and research staff who have contributed to or enabled the research discussed herein. The author acknowledges funding for the projects completed by the H. M. White research group referenced here: USDA AFRI Foundation Grant (2016-6701524573); USDA AFRI Critical Agriculture Research and Extension (CARE; 2015-67028-23572); USDA Hatch
(WIS01877 and WISC01878) from the Wisconsin Agricultural Experiment Station (Madison, WI); Cooperative Research Program for Agriculture Science and Technology Development (Project No. PJ012078) Rural Development Administration, Jeonju-si, Jeollabuk-do, Republic of Korea; Adisseo (Alpharetta, GA); AgSource Cooperative Services (research funding support and collaborative efforts; Verona, WI); Balchem Corp. (New Hampton, NY); Fermented Nutrition Corp. (Luxemburg, WI); Wisconsin Alumni Research Foundation (Madison, WI); and graduate student fellowships from Purina Animal Nutrition, LLC (St. Louis, MO) and VitaPlus Corporation (Madison, WI). The author states that there are no conflicts of interest.

\section{REFERENCES}

Adewuyi, A. A., E. Gruys, and F. J. C. M. van Eerdenburg. 2005. Nonesterified fatty acids (NEFA) in dairy cattle. A review. Vet. Q. 27:117-126. https://doi.org/10.1080/01652176.2005.9695192.

Akiyama, M., K. Sakai, C. Takayama, T. Yanagi, Y. Yamanaka, J. R. McMillan, and H. Shimizu. 2008. CGI-58 is an $\alpha / \beta$-hydrolase within lipid transporting lamellar granules of differentiated keratinocytes. Am. J. Pathol. 173:1349-1360. https://doi.org/10.2353/ ajpath.2008.080005.

Aschenbach, J. R., N. B. Kristensen, S. S. Donkin, H. M. Hammon, and G. B. Penner. 2010. Gluconeogenesis in dairy cows: the secret 
of making sweet milk from sour dough. IUBMB Life 62:869-877. https://doi.org/10.1002/iub.400.

Barletta, R. V., M. Maturana Filho, P. D. Carvalho, T. A. Del Valle, A. S. Netto, F. P. Rennó, R. D. Mingoti, J. R. Gandra, G. B. Mourão, P. M. Fricke, R. Sartori, E. H. Madureira, and M. C. Wiltbank. 2017. Association of changes among body condition score during the transition period with NEFA and BHBA concentrations, milk production, fertility, and health of Holstein cows. Theriogenology 104:30-36. https://doi.org/10.1016/j.theriogenology.2017.07.030.

Baumgard, L. H., and R. P. Rhoads Jr.. 2013. Effects of heat stress on postabsorptive metabolism and energetics. Annu. Rev. Anim. Biosci. 1:311-337. https://doi.org/10.1146/annurev-animal-031412 -103644 .

Berg, J. M., J. L. Tymoczko, and L. Stryer. 2002. Biochemistry. 5th edition. W. H. Freeman, New York.

Bernard, L., C. Leroux, and Y. Chilliard. 2008. Expression and nutritional regulation of lipogenic genes in the ruminant lactating mammary gland. Pages 67-108 in Bioactive Components of Milk. Z. Bösze, ed. Springer, New York, NY.

Bionaz, M., C. R. Baumrucker, E. Shirk, J. P. Vanden Heuvel, E. Block, and G. A. Varga. 2008. Characterization of Madin-Darby bovine kidney cell line for peroxisome proliferator-activated receptors: Temporal response and sensitivity to fatty acids. J. Dairy Sci. 91:2808-2813. https://doi.org/10.3168/jds.2007-0789.

Bionaz, M., B. J. Thering, and J. J. Loor. 2012. Fine metabolic regulation in ruminants via nutrient-gene interactions: Saturated long chain fatty acids increase expression of genes involved in lipid metabolism and immune response partly through PPAR-alpha activation. Br. J. Nutr. 107:179-191. https://doi.org/10.1017/ S0007114511002777.

Bobe, G., J. W. Young, and D. C. Beitz. 2004. Invited review: Pathology, etiology, prevention, and treatment of fatty liver in dairy cows. J. Dairy Sci. 87:3105-3124. https://doi.org/10.3168/jds .S0022-0302(04)73446-3.

Bradford, B., and T. Swartz. 2019. Do inflammatory signals play a role in metabolic homeostasis and homeorhesis of dairy cattle? Advances in Animal Biosciences. 10:382. (Abstr.) https://doi.org/ 10.1017/S2040470019000037.

Caputo Oliveira, R., K. J. Sailer, H. T. Holdorf, C. R. Seely, R. S. Pralle, M. B. Hall, N. M. Bello, and H. M. White. 2019. Postpartum supplementation of fermented ammoniated condensed whey improved feed efficiency and plasma metabolite profile. J. Dairy Sci. 102:2283-2297. https://doi.org/10.3168/jds.2018-15519.

Chandler, T. L., and H. M. White. 2019. Glucose metabolism is differentially altered by choline and methionine in bovine neonatal hepatocytes. PLOS One 14:e0217160. https://doi.org/10.1371/ journal.pone.0217160.

Chen, Z. Y., and S. C. Cunnane. 1992. Preferential retention of linoleic acid-enriched triacylglycerols in liver and serum during fasting. Am. J. Physiol. 263:R233-R239. https://doi.org/10.1152/ajpregu .1992.263.2.R233.

Corbin, K. D., M. F. Abdelmalek, M. D. Spencer, K.-A. da Costa, J. A. Galanko, W. Sha, A. Suzuki, C. D. Guy, D. M. Cardona, A. Torquati, A. M. Diehl, and S. H. Zeisel. 2013. Genetic signatures in choline and 1-carbon metabolism are associated with the severity of hepatic steatosis. FASEB J. 27:1674-1689. https://doi.org/ 10.1096/fj.12-219097.

Dole, V. P. 1956. A relation between non-esterified fatty acids in plasma and the metabolism of glucose. J. Clin. Invest. 35:150-154. https://doi.org/10.1172/JCI103259.

Drackley, J. K. 1999. ADSA Foundation Scholar Award. Biology of dairy cows during the transition period: The final frontier? J. Dairy Sci. 82:2259-2273. https://doi.org/10.3168/jds.s0022 -0302(99) 75474-3.

Elek, P., J. R. Newbold, T. Gaal, L. Wagner, and F. Husveth. 2008. Effects of rumen-protected choline supplementation on milk production and choline supply of periparturient dairy cows. Animal 2:1595-1601. https://doi.org/10.1017/S1751731108002917.

Emery, R. S., J. S. Liesman, and T. H. Herdt. 1992. Metabolism of long chain fatty acids by ruminant liver. J. Nutr. 122(Suppl 3):832-837. https://doi.org/10.1093/jn/122.suppl_3.832.
Erb, S. J., R. S. Pralle, and H. M. White. 2017. Coordination of adipose tissue lipolysis during the transition period in dairy cows. J. Dairy Sci. 100(Suppl 2):77. (Abstr.)

Erb, S. J., and H. M. White. 2019a. Exposure of primary bovine hepatocytes to physiologically relevant fatty acid profiles have altered gene expression. Adv. Anim. Biosci. 10:462. (Abstr.)

Erb, S. J., and H. M. White. 2019b. Knockdown of patatin-like phospholipase domain-containing protein 3 protein abundance increased cellular TG levels in primary bovine hepatocytes. Annual Meeting of the European Federation of Animal Science, Ghent, Belguim. Published in EAAP Book of Abstracts, Volume 25, 70:537. (Abstr.) https://doi.org/10.3920/978-90-8686-890-2.

Erb, S. J., and H. M. White. 2019c. Physiological concentrations of fatty acids impact lipolytic genes in primary bovine hepatocytes. Annual Meeting of the European Federation of Animal Science. 70:537. (Abstr.)

Erb, S. J., and H. M. White. 2019d. The effect of fatty acid cocktails mimicking timepoints across the transition period on lipolytic protein abundance in primary bovine hepatocytes. Adv. Anim. Biosci. 10:463. (Abstr.)

Ghosh, A. K., G. Ramakrishnan, C. Chandramohan, and R. Rajasekharan. 2008. CGI-58, the causative gene for Chanarin-Dorfman syndrome, mediates acylation of lysophosphatidic acid. J. Biol. Chem. 283:24525-24533. https://doi.org/10.1074/jbc M801783200.

Goff, J. P., and R. L. Horst. 1997. Physiological changes at parturition and their relationship to metabolic disorders. J. Dairy Sci 80:1260-1268. https://doi.org/10.3168/jds.S0022-0302(97)76055 -7 .

González-Recio, O., E. Ugarte, and A. Bach. 2012. Trans-generational effect of maternal lactation during pregnancy: A Holstein cow model. PLOS One 7:e51816. https://doi.org/10.1371/journal.pone .0051816 .

Gordon, R. S. Jr., and A. Cherkes. 1956. Unesterified fatty acid in human blood plasma. J. Clin. Invest. 35:206-212. https://doi.org/ 10.1172/JCI103265.

Granneman, J. G., H.-P. H. Moore, R. L. Granneman, A. S. Greenberg, M. S. Obin, and Z. Zhu. 2007. Analysis of lipolytic protein trafficking and interactions in adipocytes. J. Biol. Chem. 282:5726-5735. https://doi.org/10.1074/jbc.M610580200.

Granneman, J. G., H.-P. H. Moore, R. Krishnamoorthy, and M. Rathod. 2009. Perilipin controls lipolysis by regulating the interactions of AB-hydrolase containing 5 (Abhd5) and adipose triglyceride lipase (Atgl). J. Biol. Chem. 284:34538-34544. https://doi.org/10 .1074/jbc.M109.068478.

Greenberg, A. S., R. A. Coleman, F. B. Kraemer, J. L. McManaman, M. S. Obin, V. Puri, Q.-W. Yan, H. Miyoshi, and D. G. Mashek. 2011. The role of lipid droplets in metabolic disease in rodents and humans. J. Clin. Invest. 121:2102-2110. https://doi.org/10.1172/ JCI46069.

Greenfield, R. B., M. J. Cecava, T. R. Johnson, and S. S. Donkin. 2000. Impact of dietary protein amount and rumen undegradability on intake, peripartum liver triglyceride, plasma metabolites, and milk production in transition dairy cattle. J. Dairy Sci. 83:703-710. https://doi.org/10.3168/jds.S0022-0302(00)74932-0.

Grummer, R. R. 1993. Etiology of lipid-related metabolic disorders in periparturient dairy cows. J. Dairy Sci. 76:3882-3896. https://doi .org/10.3168/jds.S0022-0302(93)77729-2.

Hall, M. B., and D. R. Mertens. 2017. A 100-year review: Carbohydrates - characterization, digestion, and utilization. J. Dairy Sci. 100:10078-10093. https://doi.org/10.3168/jds.2017-13311.

Herd, R. M., and P. F. Arthur. 2009. Physiological basis for residual feed intake. J. Anim. Sci. 87(Suppl. 14):E64-E71. https://doi.org/ $10.2527 /$ jas. $2008-1345$.

Holdorf, H. T., R. S. Pralle, M. T. Lavarias, Q. Zhang, T. L. Chandler, and H. M. White. 2017. Response of patatin-like phospholipase domain-containing protein 3 abundance to fatty acid treatment in bovine primary hepatocytes. J. Dairy Sci. 100(Suppl. 2):280-281. (Abstr.)

Huang, Y., S. He, J. Z. Li, Y.-K. Seo, T. F. Osborne, J. C. Cohen, and H. H. Hobbs. 2010. A feed-forward loop amplifies nutritional 
regulation of PNPLA3. Proc. Natl. Acad. Sci. USA 107:7892-7897. https://doi.org/10.1073/pnas.1003585107.

Huntington, G. B. 1990. Energy metabolism in the digestive tract and liver of cattle: Influence of physiological state and nutrition. Reprod. Nutr. Dev. 30:35-47. https://doi.org/10.1051/rnd:19900103.

Ibeagha-Awemu, E. M., R. Li, A. A. Ammah, P.-L. Dudemaine, N. Bissonnette, C. Benchaar, and X. Zhao. 2016. Transcriptome adaptation of the bovine mammary gland to diets rich in unsaturated fatty acids shows greater impact of linseed oil over safflower oil on gene expression and metabolic pathways. BMC Genomics 17:104. https://doi.org/10.1186/s12864-016-2423-x.

Janovick Guretzky, N. A. J., D. B. Carlson, J. E. Garrett, and J. K. Drackley. 2006. Lipid metabolite profiles and milk production for Holstein and Jersey cows fed rumen-protected choline during the periparturient period. J. Dairy Sci. 89:188-200. https://doi.org/10 .3168/jds.S0022-0302(06)72083-5.

Ji, P., J. K. Drackley, M. J. Khan, and J. J. Loor. 2014. Inflammationand lipid metabolism-related gene network expression in visceral and subcutaneous adipose depots of Holstein cows. J. Dairy Sci. 97:3441-3448. https://doi.org/10.3168/jds.2013-7296.

Koltes, D. A., and D. M. Spurlock. 2011. Coordination of lipid dropletassociated proteins during the transition period of Holstein dairy cows. J. Dairy Sci. 94:1839-1848. https://doi.org/10.3168/jds.2010 -3769 .

Lass, A., R. Zimmermann, G. Haemmerle, M. Riederer, G. Schoiswohl, M. Schwiger, P. Kienesberger, J. G. Strauss, G. Gorkiewicz, and R. Zechner. 2006. Adipose triglyceride lipase-mediated lipolysis of cellular fat stores is activated by CGI-58 and defective in ChanarinDorfman syndrome. Cell Metab. 3:309-319. https://doi.org/10 .1016/j.cmet.2006.03.005.

Lima, F. S., M. F. Sá Filho, L. F. Greco, and J. E. P. Santos. 2012. Effects of feeding rumen-protected choline on incidence of diseases and reproduction of dairy cows. Vet. J. 193:140-145. https://doi .org/10.1016/j.tvjl.2011.09.019.

Mach, N., A. A. A. Jacobs, L. Kruijt, J. van Baal, and M. A. Smits. 2011. Alteration of gene expression in mammary gland tissue of dairy cows in response to dietary unsaturated fatty acids. Animal 5:1217-1230. https://doi.org/10.1017/S1751731111000103.

Martin, M. J., S. J. Erb, E. T. Ronk, S. J. Bertics, M. R. Moede, K. A. Weigel, and H. M. White. 2019. Differences in mammary gland uptake of post-absorptive energy metabolites may contribute to residual feed intake variation. J. Dairy Sci. 102(Suppl. 1):230. (Abstr.)

Mathews, A. T., J. E. Rico, N. T. Sprenkle, A. L. Lock, and J. W. McFadden. 2016. Increasing palmitic acid intake enhances milk production and prevents glucose-stimulated fatty acid disappearance without modifying systemic glucose tolerance in mid-lactation dairy cows. J. Dairy Sci. 99:8802-8816. https://doi.org/10 $.3168 /$ jds.2016-11295.

McArt, J. A. A., D. V. Nydam, G. R. Oetzel, and C. L. Guard. 2014. An economic analysis of hyperketonemia testing and propylene glycol treatment strategies in early lactation dairy cattle. Prev. Vet. Med. 117:170-179. https://doi.org/10.1016/j.prevetmed.2014 .06 .017 .

McCann, C. C., M. E. Viner, S. S. Donkin, and H. M. White. 2014. Hepatic patatin-like phospholipase domain-containing protein 3 sequence, single nucleotide polymorphism presence, protein confirmation, and responsiveness to energy balance in dairy cows. J. Dairy Sci. 97:5167-5175. https://doi.org/10.3168/jds.2014-7910.

McFadden, J. W., C. L. Girard, S. Tao, Z. Zheng, J. K. Bernard, M. Duplessis, and H. M. White. 2020. Symposium review: One-carbon metabolism and methyl donor nutrition in the dairy cow. J. Dairy Sci. 103:5668-5683. https://doi.org/10.3168/jds.2019-17319

McFadden, J. W., and J. E. Rico. 2019. Invited review: Sphingolipid biology in the dairy cow: The emerging role of ceramide. J. Dairy Sci. 102:7619-7639. https://doi.org/10.3168/jds.2018-16095.

McGuffey, R. K., L. F. Richardson, and J. I. D. Wilkinson. 2001. Ionophores for dairy cattle: Current status and future outlook. J. Dairy Sci. 84:E194-E203. https://doi.org/10.3168/jds.S0022 -0302(01)70218-4.
Meier, S., G. A. Verkerk, J. K. Kay, K. A. Macdonald, and J. R. Roche. 2013. Genetic ancestry modifies fatty acid concentrations in different adipose tissue depots and milk fat. J. Dairy Res. 80:197-204. https://doi.org/10.1017/S0022029913000034.

Opsomer, G., M. Van Eetvelde, M. Kamal, and A. Van Soom. 2016. Epidemiological evidence for metabolic programming in dairy cattle. Reprod. Fertil. Dev. 29:52-57. https://doi.org/10.1071/ RD16410.

Palmquist, D. L. 2006. Milk Fat: Origin of fatty acids and influence of nutritional factors thereon. Pages 43-92 in Advanced Dairy Chemistry, Vol. 2. Lipids. Springer, Boston, MA.

Pires, J. A. A., A. H. Souza, and R. R. Grummer. 2007. Induction of hyperlipidemia by intravenous infusion of tallow emulsion causes insulin resistance in Holstein cows. J. Dairy Sci. 90:2735-2744. https://doi.org/10.3168/jds.2006-759.

Potts, S. B., J. P. Boerman, A. L. Lock, M. S. Allen, and M. J. VandeHaar. 2015. Residual feed intake is repeatable for lactating Holstein dairy cows fed high and low starch diets. J. Dairy Sci. 98:4735-4747. https://doi.org/10.3168/jds.2014-9019.

Pralle, R. S., H. T. Holdorf, C. S. Seely, R. Caputo Oliveira, and H. M. White. 2019. Abundance of hepatic patatin-like phospholipase domain-containing protein 3 protein was inversely related to peripartum hepatic triglyceride accumulation. J. Dairy Sci. 102(Suppl. 1):271. (Abstr.)

Pralle, R. S., R. C. Oliveira, T. L. Chandler, S. J. Bertics, and H. M. White. 2015. Hepatic patatin-like phospholipase domain-containing protein 3 (PNPLA3) protein is regulated during the transition to lactation period in dairy cows. J. Dairy Sci. 98(Suppl 2):10. (Abstr.)

Pralle, R. S., and H. M. White. 2020. Symposium review: Big data, big predictions: Utilizing milk Fourier-transform infrared and genomics to improve hyperketonemia management. J. Dairy Sci. 103:3867-3873.

Rathbun, F. M., R. S. Pralle, S. J. Bertics, L. E. Armentano, K. Cho, C. Do, K. A. Weigel, and H. M. White. 2017. Relationships between body condition score change, prior mid-lactation phenotypic residual feed intake, and hyperketonemia onset in transition dairy cows. J. Dairy Sci. 100:3685-3696. https://doi.org/10.3168/ jds.2016-12085.

Reynolds, C. K., P. C. Aikman, B. Lupoli, D. J. Humphries, and D. E. Beever. 2003. Splanchnic metabolism of dairy cows during the transition from late gestation through early lactation. J. Dairy Sci. 86:1201-1217. https://doi.org/10.3168/jds.S0022-0302(03)73704 $-7$.

Rotman, Y., C. Koh, J. M. Zmuda, D. E. Kleiner, and T. J. Liang. 2010. The association of genetic variability in patatin-like phospholipase domain-containing protein 3 (PNPLA3) with histological severity of nonalcoholic fatty liver disease. Hepatology 52:894903. https://doi.org/10.1002/hep.23759

Rukkwamsuk, T., M. J. Geelen, T. A. Kruip, and T. Wensing. 2000. Interrelation of fatty acid composition in adipose tissue, serum, and liver of dairy cows during the development of fatty liver postpartum. J. Dairy Sci. 83:52-59. https://doi.org/10.3168/jds.S0022 $-0302(00) 74854-5$.

Rukkwamsuk, T., T. A. Kruip, G. A. Meijer, and T. Wensing. 1999. Hepatic fatty acid composition in periparturient dairy cows with fatty liver induced by intake of a high energy diet in the dry period. J. Dairy Sci. 82:280-287. https://doi.org/10.3168/jds.S0022 -0302(99)75234-3.

Samii, S. S., J. E. Rico, A. T. Mathews, A. N. Davis, C. L. Orndorff, L. O. Aromeh, and J. W. McFadden. 2019. Effects of body condition score on direct and indirect measurements of insulin sensitivity in periparturient dairy cows. Animal 13:2547-2555. https://doi.org/ 10.1017/S175173111900065X.

Sanders, M. A., F. Madoux, L. Mladenovic, H. Zhang, X. Ye, M. Angrish, E. P. Mottillo, J. A. Caruso, G. Halvorsen, W. R. Roush, P. Chase, P. Hodder, and J. G. Granneman. 2015. Endogenous and synthetic ABHD5 ligands regulate ABHD5-perilipin interactions and lipolysis in fat and muscle. Cell Metab. 22:851-860. https:// doi.org/10.1016/j.cmet.2015.08.023. 
Sato, H., and A. Inoue. 2006. Decrease in stearic acid proportions in adipose tissues and liver lipids in fatty liver of dairy cows. Anim. Sci. J. 77:347-351. https://doi.org/10.1111/j.1740-0929.2006 .00358.x.

Schäfers, S., D. von Soosten, U. Meyer, C. Drong, J. Frahm, A. Tröscher, W. Pelletier, H. Sauerwein, and S. Dänicke. 2018. Influence of conjugated linoleic acids and vitamin $\mathrm{E}$ on biochemical, hematological, and immunological variables of dairy cows during the transition period. J. Dairy Sci. 101:1585-1600. https://doi.org/10 $.3168 /$ jds.2017-13071.

Schären, M., J. Frahm, S. Kersten, U. Meyer, J. Hummel, G. Breves, and S. Dänicke. 2018. Interrelations between the rumen microbiota and production, behavioral, rumen fermentation, metabolic, and immunological attributes of dairy cows. J. Dairy Sci. 101:46154637. https://doi.org/10.3168/jds.2017-13736.

Sordillo, L. M. 2016. Nutritional strategies to optimize dairy cattle immunity. J. Dairy Sci. 99:4967-4982. https://doi.org/10.3168/jds 2015-10354.

Sordillo, L. M., G. A. Contreras, and S. L. Aitken. 2009. Metabolic factors affecting the inflammatory response of periparturient dairy cows. Anim. Health Res. Rev. 10:53-63. https://doi.org/10.1017/ S1466252309990016.

Speliotes, E. K., J. L. Butler, C. D. Palmer, B. F. Voight, GIANT Consortium, MIGen Consortium, NASH Clinical Research Network, and J. N. Hirschhorn. 2010. PNPLA3 variants specifically confer increased risk for histologic nonalcoholic fatty liver disease but not metabolic disease. Hepatology 52:904-912. https://doi .org/10.1002/hep.23768.

Strang, B. D., S. J. Bertics, R. R. Grummer, and L. E. Armentano. 1998. Relationship of triglyceride accumulation to insulin clearance and hormonal responsiveness in bovine hepatocytes. J. Dairy Sci. 81:740-747. https://doi.org/10.3168/jds.S0022-0302(98)75630 -9 .

Thompson, G. E., J. W. Gardner, and A. W. Bell. 1975. Oxygen-consumption, fatty-acid and glycerol uptake of liver in fed and fasted sheep during cold-exposure. Q. J. Exp. Physiol. Cogn. Med. Sci. 60:107-121. https://doi.org/10.1113/expphysiol.1975.sp002297.

Van Eetvelde, M., and G. Opsomer. 2017. Innovative look at dairy heifer rearing: effect of prenatal and post-natal environment on later performance. Reprod. Domest. Anim. 52:30-36. https://doi .org/10.1111/rda.13019.

VandeHaar, M. J., L. E. Armentano, K. Weigel, D. M. Spurlock, R. J. Tempelman, and R. Veerkamp. 2016. Harnessing the genetics of the modern dairy cow to continue improvements in feed efficiency. J. Dairy Sci. 99:4941-4954. https://doi.org/10.3168/jds .2015-10352.

Wang, S., and S. I. Koo. 1993. Evidence for distinct metabolic utilization of stearic acid in comparison with palmitic and oleic acids in rats. J. Nutr. Biochem. 4:594-601. https://doi.org/10.1016/0955 $-2863(93) 90028-\mathrm{U}$.
Weber, C., C. T. Schäff, U. Kautzsch, S. Börner, S. Erdmann, S. Görs, M. Röntgen, H. Sauerwein, R. M. Bruckmaier, C. C. Metges, B. Kuhla, and H. M. Hammon. 2016. Insulin-dependent glucose metabolism in dairy cows with variable fat mobilization around calving. J. Dairy Sci. 99:6665-6679. https://doi.org/10.3168/jds 2016-11022.

Weld, K. A., S. J. Erb, and H. M. White. 2019b. Short communication: Effect of manipulating fatty acid profile on gluconeogenic gene expression in bovine primary hepatocytes. J. Dairy Sci. 102:75767582. https://doi.org/10.3168/jds.2018-16150.

Weld, K. A., R. C. Oliveira, K. J. Sailer, H. T. Holdorf, S. J. Bertics, and H. M. White. 2019a. Hepatic pyruvate carboxylase expression at parturition differed in cows that subsequently developed hyperketonemia. J. Dairy Sci. 102(Suppl. 1):214. (Abstr.)

White, H. M. 2015. The role of TCA cycle anaplerosis in ketosis and fatty liver in periparturient dairy cows. Animals (Basel) 5:793-802.

White, H. M., S. L. Koser, and S. S. Donkin. 2011a. Characterization of bovine pyruvate carboxylase promoter 1 responsiveness to serum from control and feed-restricted cows. J. Anim. Sci. 89:17631768. https://doi.org/10.2527/jas.2010-3407.

White, H. M., S. L. Koser, and S. S. Donkin. 2011b. Differential regulation of bovine pyruvate carboxylase promoters by fatty acids and peroxisome proliferator-activated receptor- $\alpha$ agonist. J. Dairy Sci. 94:3428-3436. https://doi.org/10.3168/jds.2010-3960.

White, H. M., S. L. Koser, and S. S. Donkin. 2012. Gluconeogenic enzymes are differentially regulated by fatty acid cocktails in MadinDarby bovine kidney cells. J. Dairy Sci. 95:1249-1256. https://doi .org/10.3168/jds.2011-4644.

Zenobi, M. G., R. Gardinal, J. E. Zuniga, A. L. G. Dias, C. D. Nelson, J. P. Driver, B. A. Barton, J. E. P. Santos, and C. R. Staples, 2018. Effects of supplementation with ruminally protected choline on performance of multiparous Holstein cows did not depend upon prepartum caloric intake. J. Dairy Sci. 101:1088-1110. https://doi .org/10.3168/jds.2017-13327.

Zhu, L. H., L. E. Armentano, D. R. Bremmer, R. R. Grummer, and S. J. Bertics. 2000. Plasma concentration of urea, ammonia, glutamine around calving, and the relation of hepatic triglyceride, to plasma ammonia removal and blood acid-base balance. J. Dairy Sci. 83:734-740. https://doi.org/10.3168/jds.S0022-0302(00)74935 -6 .

Zom, R. L. G., J. van Baal, R. M. A. Goselink, J. A. Bakker, M. J. de Veth, and A. M. van Vuuren. 2011. Effect of rumen-protected choline on performance, blood metabolites, and hepatic triacylglycerols of periparturient dairy cattle. J. Dairy Sci. 94:4016-4027. https://doi.org/10.3168/jds.2011-4233.

\section{ORCIDS}

H. M. White @ https://orcid.org/0000-0001-5449-2811 